\title{
A Fungal Symbiont of the Redbay Ambrosia Beetle Causes a Lethal Wilt in Redbay and Other Lauraceae in the Southeastern United States
}

\author{
S. W. Fraedrich, Southern Research Station, USDA Forest Service, Athens, GA 30602; T. C. Harrington, Depart- \\ ment of Plant Pathology, Iowa State University, Ames 50011; R. J. Rabaglia, Forest Health Protection, USDA Forest \\ Service, Arlington, VA 22209; M. D. Ulyshen, Southern Research Station, USDA Forest Service, Athens, GA 30602; \\ A. E. Mayfield, III, Florida Department of Agriculture and Consumer Services, Division of Forestry, Gainesville \\ 32608; J. L. Hanula, Southern Research Station, USDA Forest Service Athens, GA 30602; \\ J. M. Eickwort, Florida Department of Agriculture and Consumer Services, Division of Forestry, Gainesville 32608; \\ and D. R. Miller, Southern Research Station, USDA Forest Service, Athens, GA 30602
}

\begin{abstract}
Fraedrich, S. W., Harrington, T. C., Rabaglia, R. J., Ulyshen, M. D., Mayfield, A. E., III, Hanula, J. L., Eickwort, J. M., and Miller, D. R. 2008. A fungal symbiont of the redbay ambrosia beetle causes a lethal wilt in redbay and other Lauraceae in the southeastern United States. Plant Dis. 92:215-224.

Extensive mortality of redbay has been observed in the coastal plain counties of Georgia and southeastern South Carolina since 2003 and northeastern Florida since 2005. We show that the redbay mortality is due to a vascular wilt disease caused by an undescribed Raffaelea sp. that is a fungal symbiont of Xyleborus glabratus, an exotic ambrosia beetle. Trees affected by the disease exhibit wilt symptoms that include a black discoloration of the sapwood. Redbay trees and containerized seedlings died within 5 to 12 weeks after inoculation with the Raffaelea sp. When redbay seedlings were challenged with $X$. glabratus, the beetles tunneled into $96 \%$ of the plants, $70 \%$ died, and the Raffaelea sp. was recovered from $91 \%$. X. glabratus and the Raffaelea sp. have also been associated with mortality of sassafras, and the Raffaelea sp. has been isolated from wilted pondberry and pondspice. Additional inoculation studies have shown that the Raffaelea sp. is pathogenic to sassafras, spicebush, and avocado, but not to red maple. Female adults of $X$. glabratus have paired mycangia near the mandibles, and the Raffaelea sp. is routinely isolated from the heads of beetles. The fungus is apparently introduced into healthy redbay during beetle attacks on stems and branches. The wilt currently affecting redbay and sassafras represents a major threat to other members of the Lauraceae indigenous to the Americas, including avocado in commercial production.
\end{abstract}

Extensive mortality of redbay (Persea borbonia (L.) Spreng.) has been observed in the lower coastal plains of South Carolina and locations around Savannah, GA since 2003. Initial reports of the mortality suggested that the problem might be drought related, but direct evidence for this was lacking and no explanation was provided for the localized nature of the mortality. During a site visit to Hilton Head Island, SC in November 2004, many dead redbay trees were found, as well as live trees exhibiting varying levels of branch dieback. Stems and branches of affected trees had streaks of black discoloration in the sapwood, and a fungus was consistently isolated from the discolored sapwood. Beetle entrance holes were noted in

Corresponding author: Stephen Fraedrich

E-mail: sfraedrich@fs.fed.us

Accepted for publication 14 September 2007.

doi:10.1094/PDIS-92-2-0215

This article is in the public domain and not copyrightable. It may be freely reprinted with customary crediting of the source. The American Phytopathological Society, 2008. stems and branches of many affected trees, and several species of ambrosia beetles (Coleoptera: Curculionidae, Scolytinae) were also found in symptomatic redbay samples, including Xyleborinus gracilis Eichhoff, Ambrosiodmus obliquus LeConte, and Xyleborus glabratus Eichhoff. The two former beetles are native to the southeastern United States, but X. glabratus is an exotic beetle reported only once before in the United States at Port Wentworth, GA in 2002 (37). The beetle is native to Southeast Asia (e.g., India, Japan, and Taiwan), where it is often associated with plant species in the family Lauraceae (e.g., Lindera latifolia Hk.f and Litsea elongata (Nees) Hk.f.) (50).

Little is currently known about the biology of $X$. glabratus, although we assume that it is typical of other ambrosia beetles, which do not consume wood but build gallery systems in wood to cultivate symbiotic fungi as food for their larvae (28). Many xylem-inhabiting ambrosia beetles and some bark beetles carry their symbiotic fungal associates in spore-bearing sacs called mycangia, which can vary greatly in morphology and location among beetle species $(22,45)$. The majority of ambrosia fungi have been assigned to the anamorphic genera Ambrosiella or Raffaelea $(3,22)$, and subsequent phylogenetic studies have found close relationships between these anamorphs and the ascomycetaceous genera Ceratocystis and Ophiostoma $(7,24,40)$. Many bark beetles, including ambrosia beetles, have mutualistic associations with species in these genera of ascomycetes, and it is thought that the ambrosia beetle symbionts are asexual derivatives of Ceratocystis and Ophiostoma (22).

Redbay is an attractive, aromatic, evergreen tree that is common in forests of the Atlantic and Gulf Coastal Plains of the southeastern United States (5). Confusion currently exists regarding the taxonomy of $P$. borbonia and other possible taxa in the southeastern United States (6). Some botanists recognize swampbay ( $P$. palustris (Raf) Sarg.) as an additional Persea species $(10,41)$, but others consider swampbay (P. borbonia var. pubescens (Pursh) Little) to be a variety of redbay $(8,29)$ or do not recognize it as a distinct species or variety $(5,14,38)$. In this paper, we refer to redbay as $P$. borbonia sensu lato without attempting to discern species or varietal differences, except in a pathogenicity test where we obtained seedlings from a commercial nursery that listed the seedlings as swampbay ( $P$. palustris). Species in the genus Persea are members of the family Lauraceae, which includes many important species of plants worldwide, including avocado (P. americana Mill.).

Redbay in the broadest sense can tolerate a wide variety of sites ranging from xeric to mesic to swampy, and the species is suitable for many landscape applications (16). Redbay is regarded as a minor-use hardwood, and the wood is occasionally used for interior finishing, cabinets, and furniture (5). Trees are small to medium size and are reported to grow as much as 18 to $21 \mathrm{~m}$ high and 60 to $90 \mathrm{~cm}$ in diameter (5). The fruit is eaten by songbirds, wild turkey, and other animals and deer browse on the foliage (5). Redbay also serves as a primary larval host for the palamedes swallowtail (Papilio palamedes Drury) (43). 
Insects and diseases have not caused serious damage to redbay in the past $(5,16)$. Since our initial evaluations on Hilton Head Island, many additional sites with redbay mortality have been found and evaluated in Georgia, Florida, and South Carolina. The vascular discoloration, $X$. glabratus, and the unidentified fungus have been associated with dead and dying redbay trees in coastal areas of South Carolina, Georgia, and northeast Florida. In addition, mortality of sassafras (Sassafras albidum (Nuttall) Nees), another member of the Lauraceae, has been observed in several coastal counties of Georgia and $X$. glabratus and the unidentified fungus were associated with these trees.

The objectives of this study were to: i) assess the distribution and determine the cause of the mortality of redbay in the southeastern United States; ii) evaluate the pathogenicity of the unidentified fungus to redbay and other members of the Lauraceae found in the southeastern United States; and iii) determine the association of the unidentified fungus with $X$. glabratus.

\section{MATERIALS AND METHODS}

Field survey and assessment of disease development. Natural forests as well as urban and residential areas with dead and symptomatic redbay trees were located on the basis of information from state forestry and pest management personnel, managers of state and federal parks, landowners, and USDA Forest Service personnel. Representative locations with redbay that exhibited symptoms of wilt were selected and samples were collected, placed in plastic bags, and transported to the USDA Forest Service Laboratory in Athens, GA. In the laboratory, samples of branch and stem sections were dissected to locate beetle galleries and identify the species of beetle when present. Sections of branches and stems with sapwood discoloration were surface sterilized by dipping the sections in $95 \%$ ethyl alcohol and flaming. Wood chips were removed from samples and placed on malt extract agar (MEA; $2.5 \%$ malt extract and $2.0 \%$ agar) or cycloheximide-streptomycin malt agar (CSMA; $1 \%$ malt extract, $1.5 \%$ agar, and $200 \mathrm{ppm}$ of cycloheximide and $100 \mathrm{ppm}$ of streptomycin sulfate added after autoclaving), a medium selective for Ophiostoma spp. and their related anamorphs (19). Evaluations of isolation plates were typically performed 7 to 10 days after plating. Morphological and molecular characterizations of an unidentified fungus associated with the sapwood discoloration were performed in laboratories at Iowa State University. Amplification and sequencing of the small subunit (SSU) rDNA and the large subunit (LSU) of the rDNA were performed as described in Cassar and Blackwell (7) and Paulin and Harrington (36).

An assessment of the rate of tree mortality in an affected forest was initiated in
July 2005 at the Timucuan Ecological and Historic Preserve (National Park Service) on Fort George Island (Duval County), FL. Redbay mortality on the site was first observed during the fall of 2004 , and approximately one-third of the largest diameter redbay were dead by July 2005 . Five (0.08-ha) circular plots were established along a $1.1-\mathrm{km}$ section of park road where dead and wilting redbays were observed. Plot centers were established approximately $20 \mathrm{~m}$ from the road and at least 70 $\mathrm{m}$ apart and all were located within the same hardwood hammock forest type dominated by live oak (Quercus virginiana Mill.), redbay, red cedar (Juniperus virginiana L.), southern magnolia (Magnolia grandiflora L.), and cabbage palm (Sabal palmetto (Walter) Lodd. ex Schult. \& Schult.f.). In each plot, every redbay with a diameter at breast height (dbh; diameter at $1.4 \mathrm{~m}$ high) greater than $2.5 \mathrm{~cm}$ was tagged and visually rated for crown condition (i.e., foliage primarily green, wilting, or brown). Trees with primarily brown or wilting foliage were considered dead. Ratings were made every 3 months through December 2006. A total of 132 trees with a greater than $2.5-\mathrm{cm}$ dbh were monitored in the five plots. In July 2006, a 0.01 ha circular subplot was added to the center of each plot, and all redbay stems less than $2.5-\mathrm{cm} \mathrm{dbh}$ and at least $15 \mathrm{~cm}$ tall were counted and rated as alive or dead.

Pathogenicity tests, growth chamber. The initial pathogenicity test in May 2005 utilized 30 redbay seedlings that were 2 to 3 years old and grown in 3.8- or 11.4-liter (1- or 3-gallon) containers with a commercial nursery mix. The mean plant height and diameter at the groundline were $63 \mathrm{~cm}$ and $10 \mathrm{~mm}$, respectively. Before inoculation, seedlings were grown in a greenhouse for a minimum of 1 month with temperatures generally between 20 and $35^{\circ} \mathrm{C}$ and no supplemental lighting.

The inoculation study utilized two single-spore isolates $(\mathrm{HH} 2=\mathrm{C} 2266$ and $\mathrm{HH} 5$ $=\mathrm{C} 2428$ ) of the unknown fungus isolated from symptomatic redbay trees on Hilton Head Island, SC. The isolates were grown on MEA for 14 days. Conidia were collected by flooding plates with approximately $20 \mathrm{ml}$ of sterile deionized water, loosening conidia with a glass rod, and passing the suspension through 3-ply sterile gauze. Spore concentrations were determined with a haemacytometer and ranged from $1.5 \times 10^{6}$ to $2.6 \times 10^{6}$ conidia $/ \mathrm{ml}$.

Fifteen redbay seedlings were wounded by drilling holes $(2 \mathrm{~mm}$ in diameter and 3 to $7 \mathrm{~mm}$ deep) into the stem at 4 to $7 \mathrm{~cm}$ above groundline and another 15 seedlings were wounded by slitting stems to a depth of approximately one-third the diameter of the stem. Five seedlings of each wound type were inoculated with $0.1 \mathrm{ml}$ of conidial suspension from one of the two fungal isolates. The other five seedlings of each wound type served as controls, and $0.1 \mathrm{ml}$ of sterile water was placed into the wound. Inoculation points on all seedlings were wrapped with Parafilm M (Pechiney Plastic Packaging, Menasha, WI). Seedlings were placed in a growth chamber with a 16-h photoperiod and day and night temperatures were set at 28 and $25^{\circ} \mathrm{C}$, respectively. After 9 weeks, disease symptoms were evaluated and pieces of stem tissue from 10 to $20 \mathrm{~cm}$ above the inoculation points were surface sterilized and plated on CSMA.

A second test was established in June 2006 to assess possible variation in pathogenicity among isolates. Ten isolates of the unknown fungus were obtained from symptomatic redbay and sassafras trees at various locations within the known range of the disease. Seedlings were 2 to 3 years old and averaged $82 \mathrm{~cm}$ high and $12 \mathrm{~mm}$ in diameter at groundline. Inoculum for each isolate was produced as previously described, and inoculum concentrations for the isolates ranged from $2.6 \times 10^{6}$ to $2.8 \times$ $10^{7}$ conidia/ml. Fifty seedlings were wounded with a drill bit as previously described and five seedlings were inoculated with $0.1 \mathrm{ml}$ of the spore suspension of each fungal isolate. An additional five seedlings were wounded and inoculated with $0.1 \mathrm{ml}$ of sterile deionized water. Seedlings were placed in a growth chamber with the photoperiod and temperature conditions previously described. After 5 weeks, seedlings were evaluated for symptoms and pieces of wood were plated on CSMA to determine the presence of the inoculated fungus.

Pathogenicity test, field. A pathogenicity test was conducted at a field site in the Victoria Bluff Heritage Preserve near Bluffton, SC, where mortality of redbay due to the wilt had been previously observed. Twenty-four redbay trees that showed no evidence of wilt were selected and paired on the basis of size and proximity to one another. Tree heights ranged from 1.8 to $4.9 \mathrm{~m}$ and tree diameters ranged from 2.1 to $6.2 \mathrm{~cm}$ at groundline. One tree of each pair was inoculated with one of two isolates $(\mathrm{HH} 1=\mathrm{C} 2265$ or $\mathrm{HH} 2$ $=\mathrm{C} 2266$ ) of the unknown fungus on 3 or 17 March 2005; the other tree of each pair was treated as a control. A hole $(5 \mathrm{~mm}$ in diameter and 1 to $2 \mathrm{~cm}$ deep) was drilled into each tree between 0.6 to $1.2 \mathrm{~m}$ above groundline. The isolates were grown on MEA and an agar plug with the fungus was inserted into the drilled holes for all fungus-inoculated trees. Seven of the control trees received a sterile agar plug and the other five control trees received no agar plug. Inoculation points were wrapped with Parafilm. Trees were evaluated on 9 June 2006 and representative samples were obtained from the stems of all trees, placed in plastic bags, transported in coolers with ice packs, and then stored at 4 to $6^{\circ} \mathrm{C}$ for 1 week before isolations were attempted. Pieces of wood from all trees were surface 
sterilized, plated on CSMA, and incubated as previously described. Plates were evaluated after 7 to 10 days for the presence of the inoculated fungus.

Pathogenicity to other species. The susceptibility of sassafras, spicebush (Lindera benzoin (L.) Blume), and swampbay to the wilt fungus was compared with that of redbay in a growth chamber test in August 2005. All seedlings were grown in 3.8- or 11.4-liter pots. The mean diameters at groundline and heights of plant species ranged from 8.5 to $12 \mathrm{~mm}$ and 62 to 100 $\mathrm{cm}$, respectively. Inoculum of isolates $\mathrm{HH} 1$ and $\mathrm{HH} 2$ was prepared as previously described, and inoculum concentrations ranged from 4.8 to $6.4 \times 10^{6} \mathrm{condia} / \mathrm{ml}$. For each plant species, 15 seedlings were wounded with a 2.8 -mm-diameter drill bit to a depth approximately one-half of the diameter of the stems, and five seedlings were inoculated with one of the two fungal isolates or sterile water as previously described. Seedlings were placed in a growth chamber with a 16-h photoperiod and day and night temperatures at 28 and $25^{\circ} \mathrm{C}$, respectively. After 5 weeks, the seedlings were evaluated for symptoms and representative stem samples were plated on CSMA and evaluated for the presence of the fungus as previously described.

The susceptibility of avocado (P. americana) to wilt caused by the unknown fungus was evaluated in a growth-chamber test in February 2006. Seedlings were obtained from a nursery in south Florida and were grown in 3.8-liter pots. Seedlings were less than 1 year old with a mean diameter of $10.8 \mathrm{~mm}$ and height of $47 \mathrm{~cm}$. Inoculum of isolates HH1 and HH5 was prepared as previously described and concentrations ranged from 2.0 to $3.5 \times 10^{6}$ conidia $/ \mathrm{ml}$. Thirty seedlings were wounded with a drill bit $(2.8 \mathrm{~mm}$ in diameter $)$ and 10 seedlings were inoculated with one of the two fungal isolates or sterile water as previously described. Seedlings were placed in a growth chamber with a 16-h photoperiod and day and night temperatures at 28 and $25^{\circ} \mathrm{C}$, respectively. After 4 weeks, seedlings were evaluated for external symptoms on foliage and shoots. After 8 weeks, the seedlings were evaluated again for symptoms and representative stem samples from seedlings were plated on CSMA as previously described.

The susceptibility of red maple (Acer rubrum $\mathrm{L}$.) to wilt caused by the unknown fungus was evaluated in a growth chamber test in April 2006. Seedlings were grown in 11.4-liter pots and were 2 years of age when inoculated. The mean diameter of seedlings was $14.5 \mathrm{~mm}$ and the mean height was $90 \mathrm{~cm}$. Inoculum of isolates $\mathrm{HH} 1$ and $\mathrm{HH} 2$ was prepared as previously described and inoculum concentrations ranged from 5.7 to $6.6 \times 10^{6}$ conidia $/ \mathrm{ml}$. Fifteen seedlings were wounded with a drill bit ( $2.8 \mathrm{~mm}$ in diameter) and five seedlings were inoculated with one of the two isolates or sterile water as previously described. Three redbay seedlings were also inoculated with the inoculum from each isolate to confirm pathogencity. Seedlings were placed in a growth chamber with a 16-h photoperiod and day and night temperatures at 28 and $25^{\circ} \mathrm{C}$, respectively. After 8 weeks, the seedlings were evaluated for symptoms and representative stem samples from the seedlings were plated on CSMA as previously described.

Mycangia of $\boldsymbol{X}$. glabratus. Ten female $X$. glabratus adults, freshly emerged from infested bolts, were examined for the presence of mycangia. Beetles were fixed in Carnoy's solution and then soaked in phenol for 1 week, a modification of a tech-

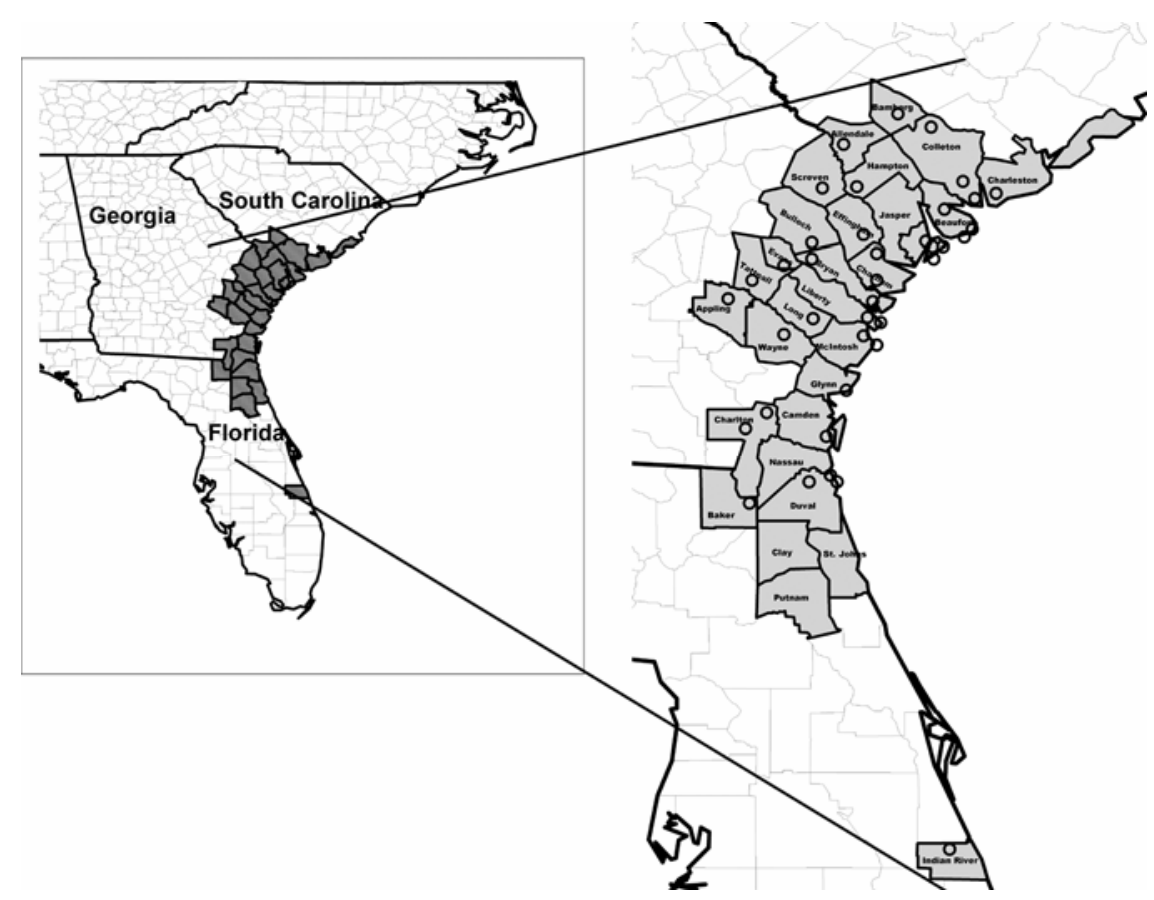

Fig. 1. Locations (O) in Georgia, South Carolina, and Florida at which the Raffaelea sp. has been isolated from dead and dying redbay trees. Counties where the disease has been observed are shaded.

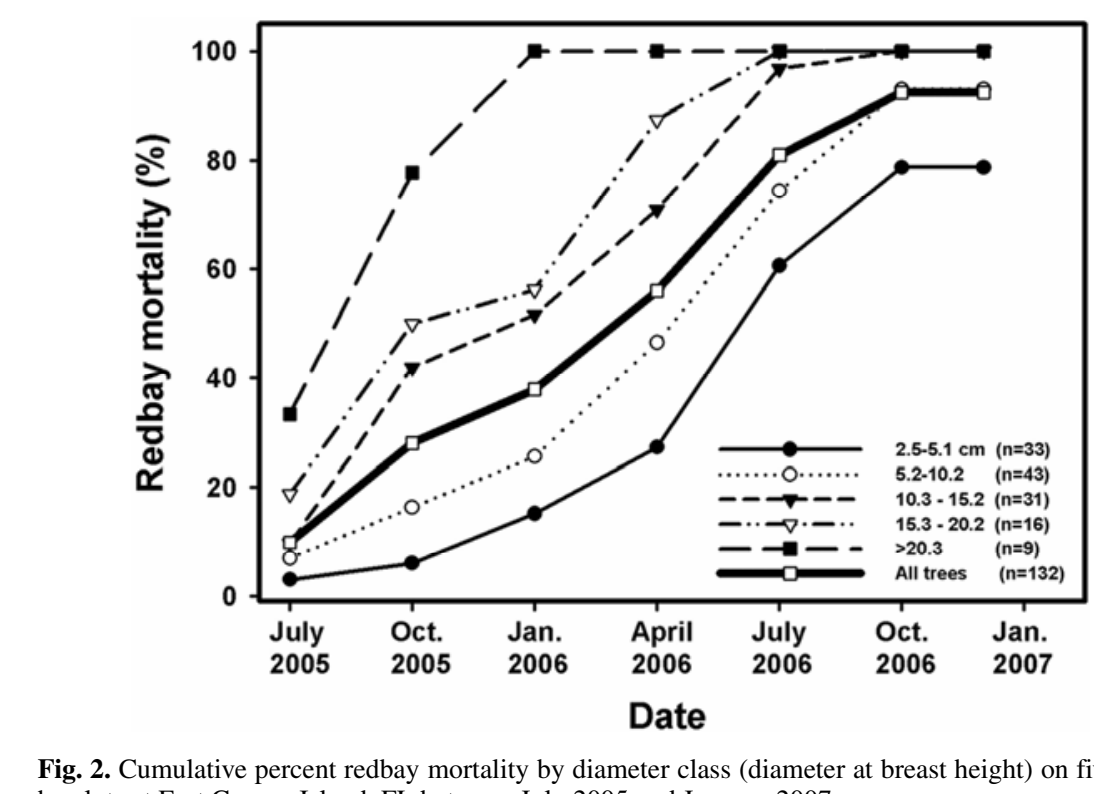

Fig. 2. Cumulative percent redbay mortality by diameter class (diameter at breast height) on five 0.08ha plots at Fort George Island, FL between July 2005 and January 2007.

nique by Schedl (42), to soften the cuticle. A rotary microtome was used to cut 8 - to $12-\mu \mathrm{m}$ transverse and longitudinal sections. The sections were stained with Harris-hematoxylin and eosin-phloxine (30) and observed with a light microscope.

Ten additional, recently emerged female beetles from infested bolts were used to determine the association of fungal propagules of the unknown fungus with the head, thorax, and abdomen. Body parts were aseptically separated and individually placed in a sterile ceramic mortar with 0.1 $\mathrm{ml}$ of sterile deionized water and thoroughly ground. An additional $1 \mathrm{ml}$ of sterile deionized water was then added to the mortar. The suspension was mixed and 0.1

Plant Disease / February 2008 
$\mathrm{ml}$ was placed on each of three petri plates containing CSMA. The suspension was spread over the plates with a sterile glass rod and plates were incubated at $25^{\circ} \mathrm{C}$. Plates were examined after 7 to 8 days and the number of fungal colonies was determined. Numbers of colony forming units per beetle body part were expressed as a mean of the three plates.

Plants challenged with $X$. glabratus. Two experiments were conducted to evaluate the potential for $X$. glabratus to tunnel into plants and introduce the pathogen. In the first experiment, 23 redbay seedlings were challenged with $X$. glabratus in October 2005. The mean height of seedlings used in the experiment was $48 \mathrm{~cm}$ and the mean diameter at groundline was $10.2 \mathrm{~mm}$. Beetles were reared from bolts of naturally infested, diseased redbay collected from the field. Individual female beetles that emerged from bolts were placed in gel capsules, and the capsules were attached to healthy seedlings by lightly scoring the stems with a cork borer approximately 4 to $5 \mathrm{~cm}$ above the groundline and inserting the edge of one-half of the capsule with the beetle into the resulting groove. Beetles that died within $24 \mathrm{~h}$ after attachment of the capsules to stems were replaced. Six additional redbay seedlings were scored with a cork borer and capsules without beetles were attached; these seedlings served as nonchallenged controls. All seed- lings were observed for symptoms over the course of the next 8 weeks. At the end of the experiment, seedlings were evaluated for tunnel development and symptoms and representative samples of wood from all seedlings were plated on CSMA medium and subsequently evaluated for the presence of the fungus.

A second experiment was initiated in April 2006. Redbay, sassafras, spicebush, red maple, and white oak (Quercus alba L.) were challenged with $X$. glabratus adults reared from bolts of infested and diseased trees. All seedlings were grown in 3.8- or 11.4-liter containers, and the mean diameters at groundline varied among species from 11.2 to $14.0 \mathrm{~mm}$ and mean
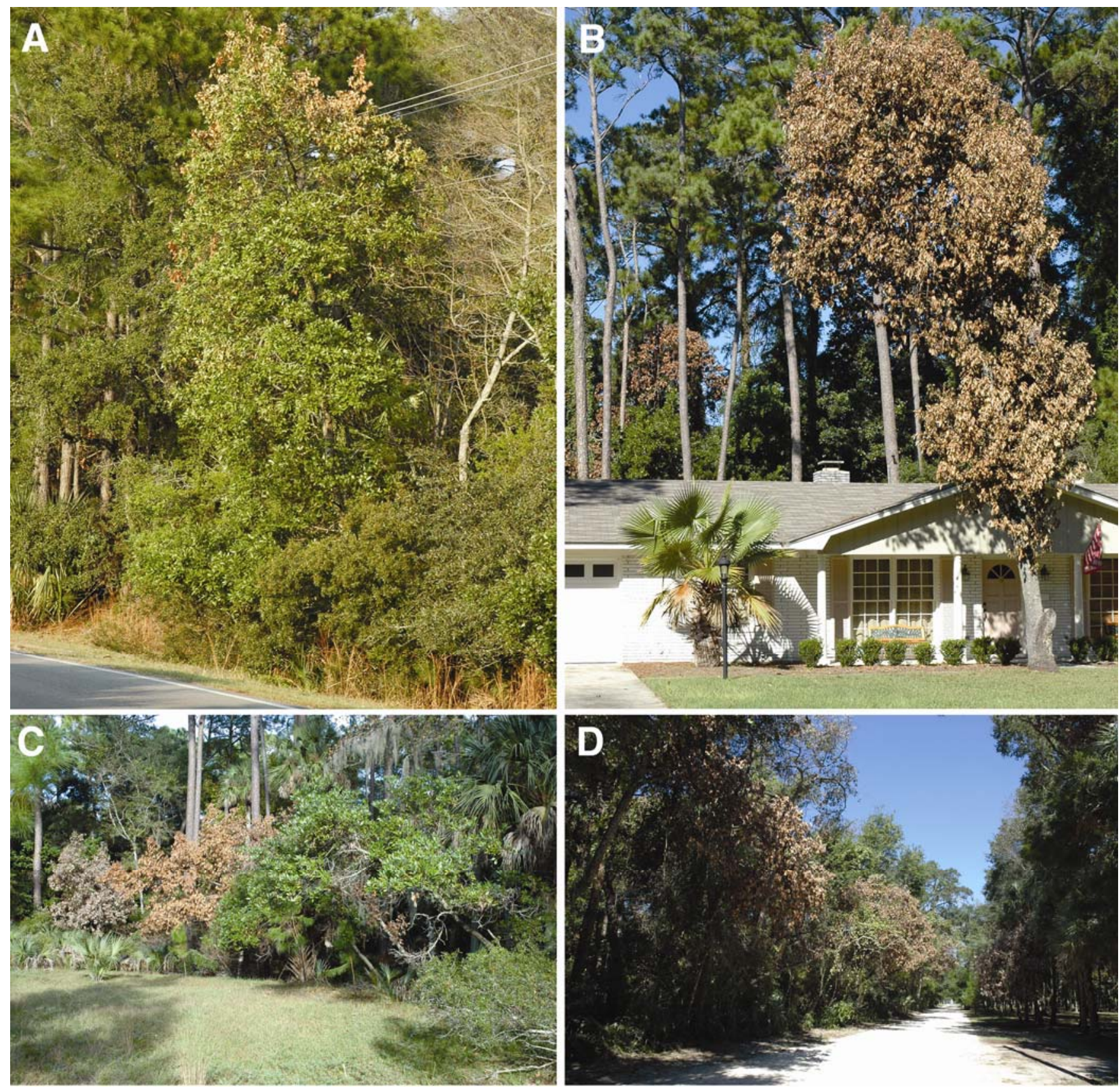

Fig. 3. Examples of wilted redbay trees in the southeastern United States caused by a Raffaelea sp. A, Redbay in the initial stages of wilt at Hunting Island State Park, SC in March 2006. B, Wilted redbay in a residential area of Jekyll Island, GA in October 2006. C, Wilted and nonsymptomatic redbay at Hunting Island State Park, SC in October 2005. D, Wilted redbay trees at the Timucuan Ecological and Historic Preserve on Ft. George Island, FL in November 2005. 
heights ranged from 87 to $129 \mathrm{~cm}$. For each species, 9 to 11 seedlings were scored with a cork borer and challenged with $X$. glabratus as previously described. Beetles that died within $24 \mathrm{~h}$ after placement on stems were replaced. Seedlings were observed over the course of the next 6 weeks. At the end of the experiment, seedlings were evaluated for development of tunnels and disease symptoms and representative samples of wood from all seedlings were plated on CSMA medium.

\section{RESULTS}

Field survey. Sample locations and the known range of the new disease on redbay as of January 2007 are presented in Figure 1. Sampled redbay ranged from seedlings to trees approximately $15 \mathrm{~m}$ high and 30 $\mathrm{cm}$ dbh. Diseased trees exhibited branch mortality and wilt over a portion of the tree crown or the entire crown. The characteristic black discoloration of the sapwood of stems or branches was also observed. The disease was common in urban, residential, and natural areas on a range of sites including swamps, mesic flatwoods, and xeric dune and upland coastal plain forests.

An unknown fungus was isolated from symptomatic trees at all locations sampled. The presence of $X$. glabratus in symptomatic trees was also confirmed at many of these locations. Another Asian ambrosia beetle, Xylosandrus crassiusculus Motschulsky, was also observed in stems of dead and dying redbay at many locations. At some locations, dieback of twigs and small branches of redbay was associated with attacks by a third Asian ambrosia beetle, Xylosandrus compactus (Eichhoff).

The mortality of redbay trees increased dramatically at the Timucuan Ecological and Historic Preserve over a 16-month period. The cumulative percentage of mortality among the 132 monitored redbays $(2.5-\mathrm{cm} \mathrm{dbh}$ and greater) increased from 9.8 to $92.4 \%$ between July 2005 and October 2006 (Fig. 2). Larger diameter classes died more quickly than smaller classes, and by December 2006, all redbays greater than $10.3-\mathrm{cm}$ dbh were dead. Of the 222 redbay stems less than $2.5-\mathrm{cm}$ dbh examined in the five 0.01 ha subplots established in July 2006, only one was dead in January 2007.

The diseased Persea trees that we examined were considered $P$. borbonia sensu lato. However, the symptomatic trees varied in traits that are used by some taxonomists to differentiate redbay varieties or separate species. The trees had varying degrees of pubescence on twigs and the undersides of leaves that ranged from sparse, short, appressed trichomes to abundant, long, erect, reddish or golden brown trichomes that gave the appearance of dense pubescence.

Other species of Lauraceae appear to be affected by the wilt. Wilted sassafras with sapwood discoloration has been found at four locations in Georgia, and the unidentified fungus and $X$. glabratus have been associated with the dead and dying trees. The unidentified fungus has also been isolated from wilted pondspice (Litsea aestivalis (L.) Fern.) at a location in South Carolina and at another location in Geor-
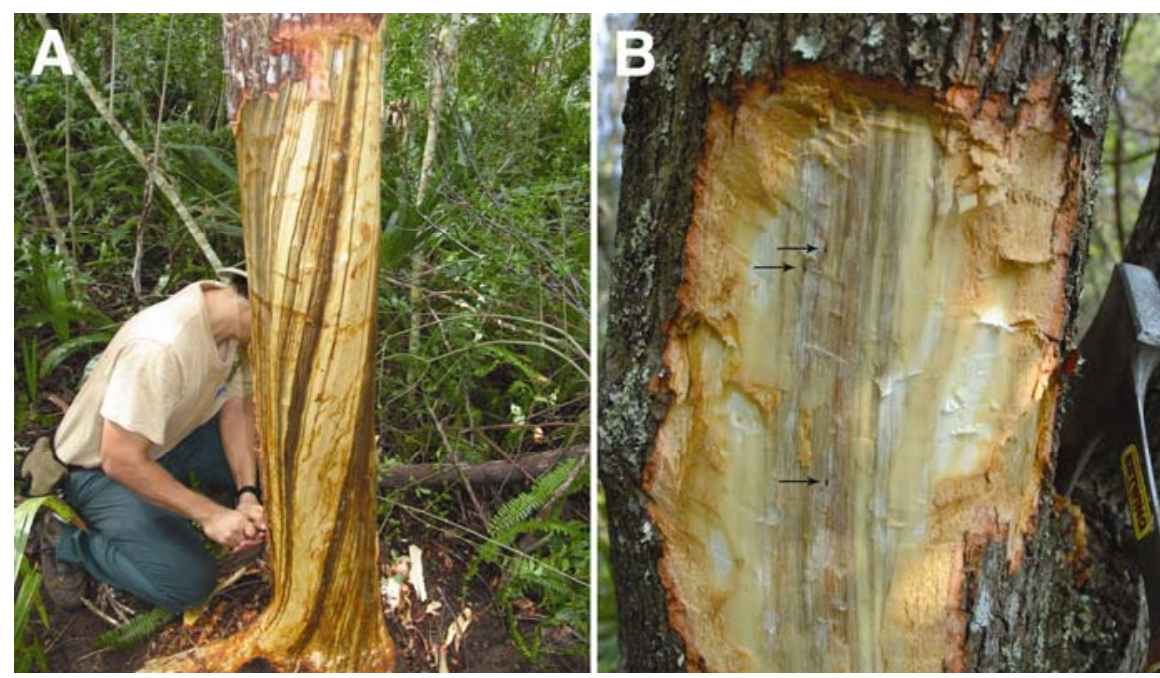

Fig. 4. A, Sapwood discoloration and streaking in wilted redbay (Fort George Island, FL). B, Close-up of sapwood discoloration with tunnel entrance holes (arrows) made by Xyleborus glabratus.

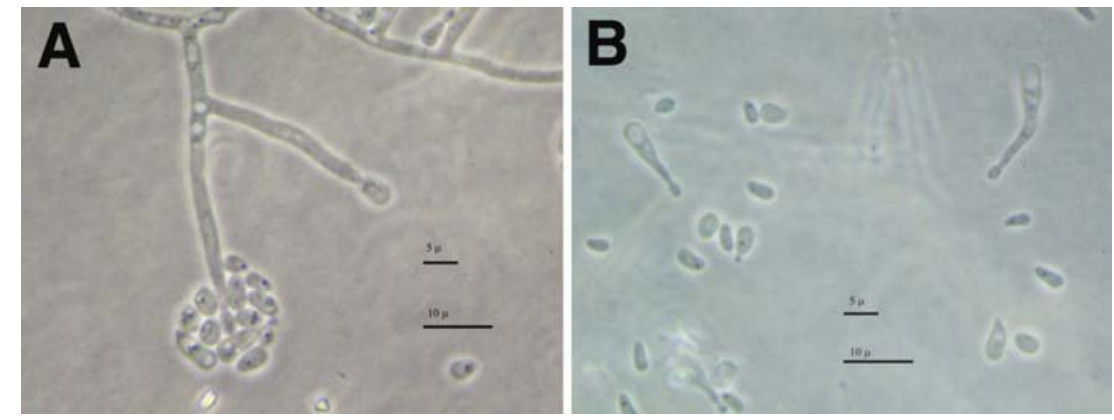

Fig. 5. Microscopic characteristics of the Raffaelea sp. on malt extract agar. A, Conidia, conidiophores, and budding yeast-like spores. B, Conidia and budding yeast-like spores.

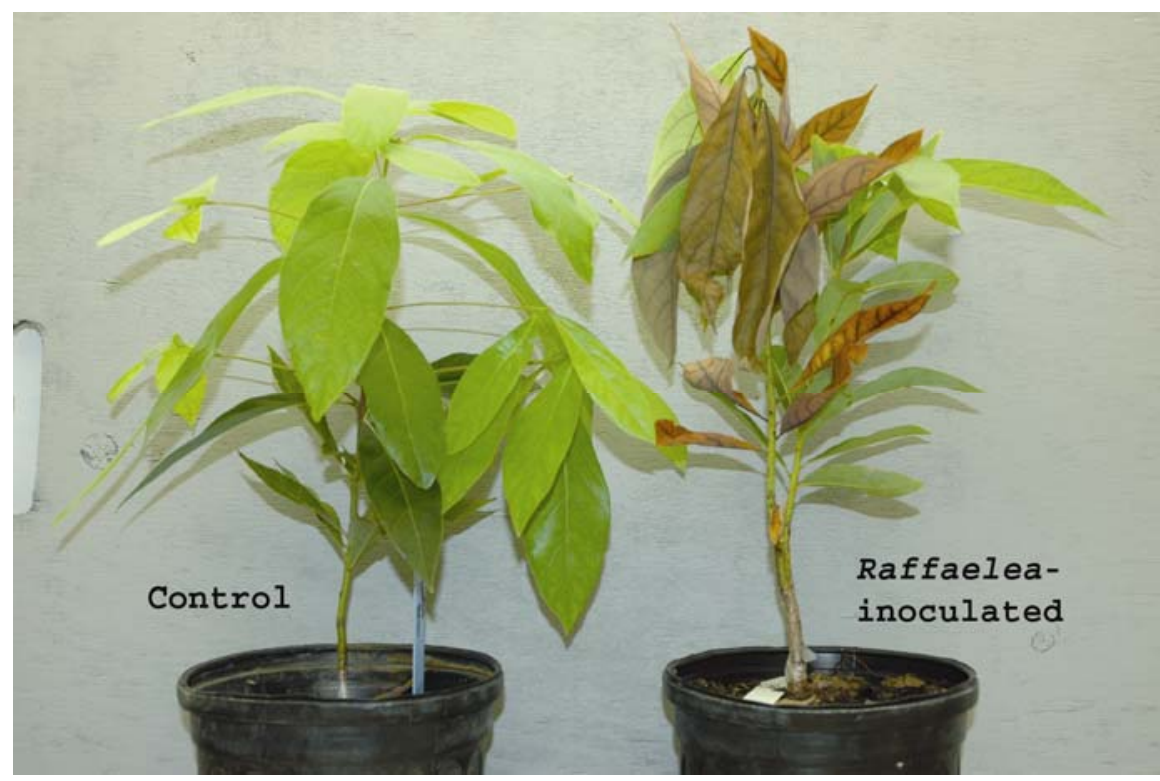

Fig. 6. Redbay seedlings 5 weeks after inoculation with the Raffaelea sp. pondberry (Lindera melissifolia ated with the dead pondspice or pondberry.

Disease and fungus description. In the early stages of the disease, some trees gia. The fungus was also isolated from far, we have not fou $X$. glabratus associ- 
exhibited wilting of branch tips throughout the crown, or dieback and wilting of individual branches (Fig. 3A). During the spring and summer months, trees frequently exhibited uniform wilting of foliage throughout the entire crown and the trees died rapidly (Fig. 3B-D). Dying leaves developed a red brown-to-purple brown coloration and often persisted on branches for more than 1 year after the tree died. A dark black discoloration was present in the sapwood of branches and stems of diseased trees (Fig. 4). In the early stages of wilt, the discoloration was frequently noted in the outermost sapwood and occurred as localized streaks in portions of branches and stems. As the disease progressed, the discoloration developed more extensively through the cross-sectional area of stems or branches. Small beetle entrance holes (approximately 0.75 $\mathrm{mm}$ in diameter) were frequently found in branches and stems with sapwood discoloration, but the beetle holes were sometimes rare and found only after an intensive search in the early stages of the disease. After trees have wilted and died, stems and large branches were repeatedly attacked by $X$. glabratus and other species of ambrosia beetles during the spring, summer, and fall months.

A hyaline, fast-growing fungus was consistently isolated from discolored sapwood of diseased trees. Colonies on MEA were initially yeast like, but then a submerged mycelium grew at the margins. The older portions of the colonies were very mucilaginous with abundant yeast-like growth. The advancing margin of the colonies had sparse, mostly submerged hyphae with many small conidiophores producing elon- gated conidia at the tips (Fig. 5). Conidia in turn produced blastospores and yeastlike colonies developed at the tips of the conidiophores. The conidia were highly variable in shape, mostly 4 to $9 \times 2$ to 3 $\mu \mathrm{m}$, ovate to pyriform to elongate. The conidiophores were small and hyaline and the conidiogenous cells did not have conspicuous scars or had inconspicuous annelations at the point of conidial dehiscence. The conidia and conidiophores are consistent with the generic concept of Hyalorhinocladiella, a common anamorph of Ophiostoma spp. However, an anamorph genus of ambrosia beetle symbionts, Raffaelea, also produces similar conidiophores, but in sporodochia (3), and the unknown fungus could be accurately placed in this genus. The fungus is herein referred to as Raffaelea sp. Like other Ophiostoma species and their anamorphs (18), the Raffaelea sp. tolerates high concentrations of cycloheximide and selective media containing cycloheximide have been routinely used in isolations.

Attempts to amplify the internal transcribed spacer region of the rDNA were not successful, so a portion of the SSU was amplified and sequenced (36). A BLAST (NCBI, BLASTN 2.2.1.5) search of a 1,026-bp portion of the SSU (exons only; Accession No. EU123076) matched most closely with the SSU sequence of a number of ambrosia beetle symbionts and other species in the genus Ophiostoma: Ambrosiella brunnea $(1,019 \mathrm{bp}$ in common with AY858654), Raffaelea ambrosiae (1,011 bp in common with AY497518), $R$. albimanens $(1,009$ bp in common with AY858664), $R$. canadensis (1,007 bp in common with AY858665), A. sulcati

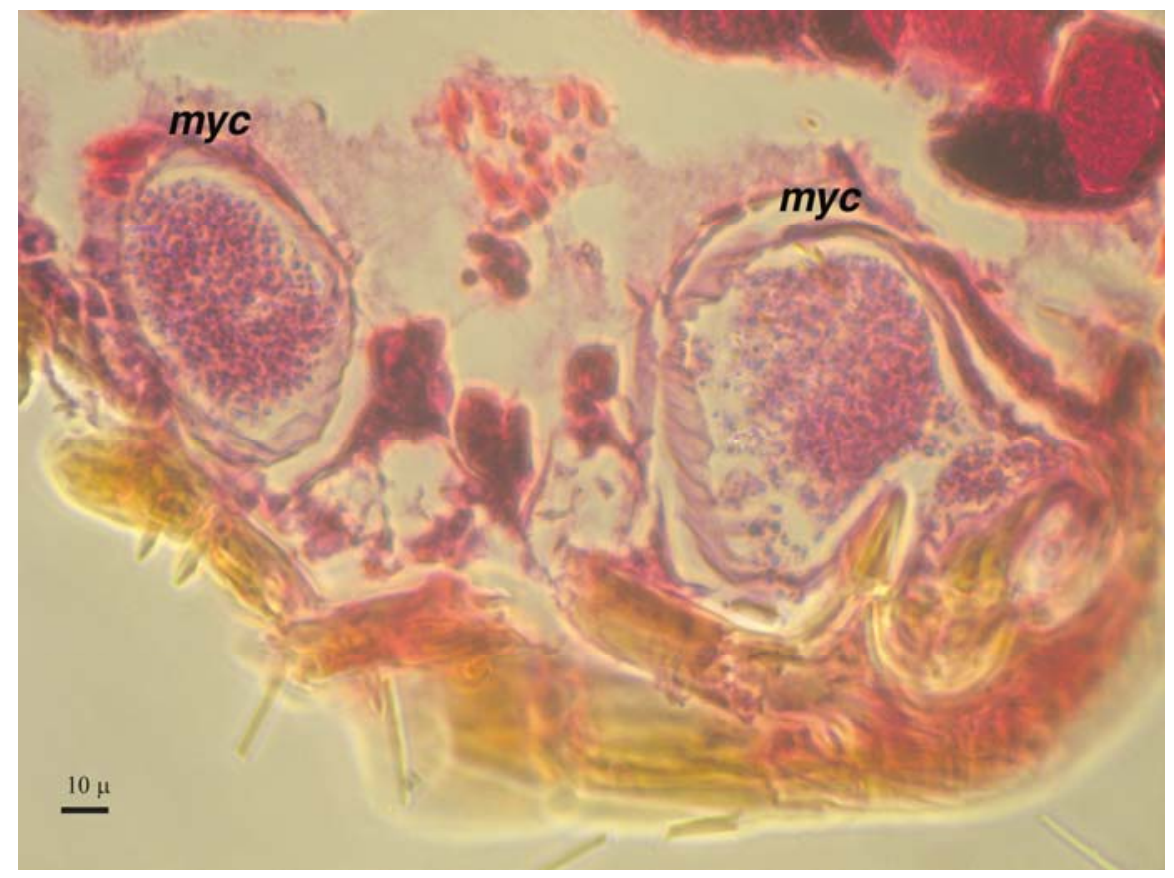

Fig. 7. Transverse section through the head of Xyleborus glabratus showing paired mandibular mycangia (myc) containing fungal spores.
(1,007 bp in common with AY858658), $O$. auraucariae $(1,007 \mathrm{bp}$ in common with AY497510), O. stenoceras (1,007 bp in common with AY858663), and Sporothrix schenckii $(1,007 \mathrm{bp}$ in common with M85053). A portion of the LSU rDNA was also sequenced, and a BLAST search with a 533-bp segment of the LSU (Accession No. EU123077) placed the fungus in the genus Ophiostoma: 498 bp of the 533-bp fragment matched with the sequence of $O$. huntii (AY707208), Leptographium yunnanense (AY707207), L. wingfieldii (AY707205), and Fragosphaeria purpurea (AF096191).

Thirty-seven isolates of the Raffaelea sp. were sequenced for the $5^{\prime}$ end of the LSU. Each of these sequences was identical to Accession No. EU123077. The sequenced isolates included those from diseased redbay in South Carolina, Georgia, and Florida, and isolates from lauraceous hosts Sassafras albidum, Lindera melissifolia, Litsea aestivalis, and from the ambrosia beetle, X. glabratus. A representative isolate was deposited in the Centraalbureau voor Schimmelcultures (CBS 121567).

Pathogenicity tests, growth chamber. In the first inoculation experiment, all redbay seedlings inoculated with the Raffaelea sp. by either the drill hole or slit treatments exhibited sapwood discoloration and 19 of 20 inoculated seedlings wilted or died within 8 weeks after inoculation (Fig. 6). One of the seedlings inoculated by the slit method exhibited sapwood discoloration but did not wilt. Leaf discoloration or wilting of shoots or leaves was observed in some seedlings within 10 days after inoculation. Often, one of the first external symptoms of infection was a dark discoloration of the midvein of some leaves. The leaves of inoculated seedlings subsequently developed a dark red brownto-purple brown discoloration and wilted. Foliar symptoms progressed to include entire branches and then entire seedlings. The Raffaelea sp. was reisolated from the discolored sapwood of all symptomatic seedlings at the end of the experiment. The 10 control seedlings remained healthy and exhibited no symptoms.

Each of the 10 isolates of the Raffaelea sp. was pathogenic to redbay in the second experiment. All but one of the 50 inoculated seedlings wilted or died, and the pathogen was recovered from the 49 symptomatic seedlings. One seedling inoculated with an isolate from Bryan County, Georgia survived and showed no sapwood discoloration and the pathogen was not recovered from this seedling. All control seedlings were healthy and did not exhibit symptoms at the end of the experiment and the pathogen was not isolated from the five control seedlings.

Pathogenicity test, field. Each of the 12 redbay trees inoculated with the Raffaelea sp. wilted within 12 to 14 weeks after inoculation and sapwood discoloration was 
observed in the stems and branches of each tree. The Raffaelea sp. was recovered from each of the 12 inoculated trees. Three of the 12 control trees also wilted, but subsequent examinations of these trees revealed that they had beetle entrance holes characteristic of $X$. glabratus as well as sapwood discoloration. The Raffaelea sp. was recovered from those three control trees. The other nine control trees were healthy with no evidence of sapwood discoloration, wilt symptoms, or beetle entrance holes and the Raffaelea sp. was not isolated from these control trees.

Susceptibility of other species. All spicebush, sassafras, swampbay, and redbay seedlings (10 inoculated seedlings of each species) wilted and died following inoculation with the Raffaelea sp. All inoculated seedlings exhibited sapwood discoloration and the pathogen was reisolated from each of the inoculated seedlings. In spicebush, leaf chlorosis and wilting was evident in some seedlings within 5 days after inoculation and most spicebush seedlings died within 3 weeks. All inoculated sassafras seedlings died within 5 weeks and leaves turned red and abscised from the stems. In redbay and swampbay, new shoots at branch terminals wilted and mature leaves developed a red brown-to-purple brown discoloration and persisted on the branches. All redbay and swampbay seedlings died within 5 weeks after inoculation. Control seedlings of all species remained healthy and exhibited no symptoms and the pathogen was not recovered.

In the test of the avocado seedlings, three of the fungus-inoculated seedlings were dead after 4 weeks, and 12 other seedlings exhibited some symptoms that included a brown discoloration and wilting of some leaves, leading to branch dieback in some of these seedlings. After 8 weeks, the 12 fungus-inoculated seedlings that had previously exhibited symptoms were still alive and there was no evidence that the disease had progressed much beyond the level observed at 4 weeks. Five of the fungus-inoculated seedlings and all of the control seedlings remained asymptomatic after 8 weeks. At the termination of the experiment, 19 of the 20 fungusinoculated seedlings had a brown discoloration in the xylem that frequently extended throughout the stems of seedlings and the Raffaelea sp. was isolated from the discolored xylem of all 19 seedlings. There was no vascular discoloration in the control seedlings and the Raffaelea sp. was not isolated.

In the test of red maple, all fungus-inoculated and control seedlings were asymptomatic with no evidence of wilting or sapwood discoloration at the end of 8 weeks. The Raffaelea sp. was not reisolated from any of the seedlings. In contrast, all fungus-inoculated redbay seedlings wilted and the Raffaelea sp. was reisolated from the discolored sapwood.
Mycangia of $X$. glabratus. Mycangia were found at the base of each mandible in each of the female $X$. glabratus examined (Fig. 7). The paired mycangia appeared to be packed with small fungal spores, and the spores were similar in size and shape to the blastospores (yeast cells) of the Raffaelea $\mathrm{sp}$.

The Raffaelea sp. was routinely recovered from the heads of $X$. glabratus adults reared from diseased bolts but was not isolated from the thoracic or abdominal sections of the same beetles. The Raffaelea sp. was recovered from heads of 9 of the 10 beetles, with a range of 5 to $182 \mathrm{CFU}$ per plate (mean $=98.4 \mathrm{CFU}$ ) and as much as 2,000 CFU per head. The fungus was not isolated from one of the 10 beetles.

Plants challenged with $X$. glabratus. Adult beetles initiated tunnels into most of the redbay plants within $48 \mathrm{~h}$ after placement on stems. At the end of the first experiment, 22 of the 23 seedlings challenged with beetles had evidence of tunnels, 17 of those plants had discolored xylem, 16 of the plants wilted or died, and the Raffaelea sp. was recovered from 21 of the plants including the 16 plants that wilted or died. The pathogen was also isolated from five of the nonsymptomatic, beetle-attacked plants, but only from the vicinity of the beetle tunnels. Control plants did not exhibit symptoms of wilt, and the Raffaelea sp. was not isolated from those plants.

In the second experiment, beetle tunnels were observed in 73 to $90 \%$ of sassafras, spicebush, and redbay plants challenged with $X$. glabratus (Table 1). Each seedling of these species that had beetle tunnels wilted, and the Raffaelea sp. was isolated from discolored sapwood of all symptomatic plants. Tunnel development was observed in $40 \%$ of the red maples challenged with adults of $X$. glabratus, but there was neither sapwood discoloration nor wilt symptoms in this species. The Raffaelea sp. was not isolated from any of the challenged red maple seedlings. There was no evidence of tunnel development in any of the white oak seedlings, and these seedlings appeared healthy at the end of the experiment with no evidence of sapwood discoloration.

Beetles were usually not present in the tunnels on attacked seedlings of any species when examined at the end of the ex- periments. Living or dead adults were found in only a few seedlings and no eggs, larvae, or pupae were observed in tunnels.

\section{DISCUSSION}

The extensive mortality of redbay in coastal plain counties of South Carolina, Georgia, and northeastern Florida is due to a new wilt disease caused by an unnamed species of Raffaelea. Other members of the Lauraceae are also affected by the disease, and we propose that the new disease be named "laurel wilt" to reflect the breadth of susceptible plant species. Females of an exotic ambrosia beetle, $X$. glabratus, carry the Raffaelea sp. in their paired mandibular mycangia. We hypothesize that the pathogen was introduced to the United States from Asia with $X$. glabratus, and the pathogen and its vector pose a major threat to members of the Lauraceae in the Americas.

The fungus responsible for the wilt falls within the genus Ophiostoma based on its tolerance to cycloheximide and rDNA sequences. A few other species in the genus are capable of causing a vascular wilt disease, that is, a disease in which the pathogen initially moves systemically through the sapwood in the nonliving vessel elements. The sapwood discoloration caused by the laurel wilt fungus is believed to be a host response to colonization of the pathogen, and the pathogen is readily isolated from all discolored vascular tissue including discolored leaf veins. The streaking pattern found in the sapwood of affected trees is similar in appearance to that in elm trees infected with Ophiostoma ulmi or O. novo-ulmi (44). Conifers do not have vessel elements, but Leptographium wageneri (teleomorph $=O$. wageneri) moves slowly through the nonliving tracheids $(20,44)$, and the sapwood discoloration in pines and Douglas-fir with black stain root disease is also similar in appearance to the sapwood discoloration in diseased redbay. The unnamed agent of laurel wilt appears to reside in a third lineage within Ophiostoma that is capable of moving systemically through their hosts in the nonliving xylem elements.

On the basis of rDNA sequences, the new pathogen is most closely related to Ambrosiella and Raffaelea species that are thought to be asexual members of the genus Ophiostoma $(7,24)$. These ambrosia

Table 1. Development of beetle tunnels, sapwood discoloration, wilt symptoms, and isolation of Raffaelea sp. in redbay (Persea borbonia), sassafras (Sassafras albidum), northern spicebush (Lindera benzoin), red maple (Acer rubrum), and white oak (Quercus alba) challenged with Xyleborus glabratus

\begin{tabular}{lccccc}
\hline & \multicolumn{5}{c}{ Number of plants } \\
\cline { 2 - 6 } Species & Challenged & $\begin{array}{c}\text { Tunnel } \\
\text { development }\end{array}$ & $\begin{array}{c}\text { Sapwood } \\
\text { discoloration }\end{array}$ & Wilted & $\begin{array}{c}\text { Raffaelea sp. } \\
\text { isolated }\end{array}$ \\
\hline Redbay & 10 & 9 & 9 & 9 & 9 \\
Sassafras & 11 & 8 & 8 & 8 & 8 \\
Spicebush & 9 & 7 & 7 & 7 & 7 \\
Red maple & 10 & 4 & 0 & 0 & 0 \\
White oak & 10 & 0 & 0 & 0 & 0 \\
\hline
\end{tabular}


beetle symbionts produce small conidiophores in tight clusters (sporodochia), which are thought to be adaptations for grazing by ambrosia beetle larvae or by some bark beetles $(3,22)$. Ambrosiella and Raffaelea are distinguished by annelidic versus sympodial proliferation of the conidiogenous cells, respectively (3), but the use of this character in delineating anamorphic genera of Ophiostoma species has been questioned (21) and this would appear to be an artificial distinction in the case of ambrosia beetle symbionts. The type species of Ambrosiella (A. xylebori Brader ex Von Arx \& Hennebert) is known to be closely related to Ceratocystis rather than Ophiostoma, leaving Raffaelea as a better anamorphic genus for the asexual symbionts of ambrosia beetles related to Ophiostoma $(7,24)$. Thus, the laurel wilt pathogen will be described in a forthcoming study as a new species of Raffaelea.

The types of mycangia found in bark and ambrosia beetles vary greatly, from simple external pits to complex invaginations of the cuticle lined with special excretory glands $(4,22,45)$. Three types of mycangia have been described for species of Xyleborus: pouches at the base of each elytron, intersegmental sacs between the pronotum and mesonotum, and paired pouches at the base of the mandibles (34). The latter type is most common in Xyleborus (4) and consistent with our observations of $X$. glabratus. Isolations of the Raffaelea sp. from the heads of X. glabra$t u s$, as well as experiments that challenged plants with the beetles, provide evidence that the Raffaelea sp. is reproducing within the mycangia of $X$. glabratus. The budding spores of the Raffaelea sp. are thought to ooze from the paired mycangia, and thus are introduced to the host xylem during beetle tunneling. Males of Xyleborus species are much smaller than the females, are generally flightless, and mate with siblings before young females emerge (37). We assume that only female $X$. glabratus have mycangia and can serve as vectors of the Raffaelea sp., but we have not studied males of $X$. glabratus.

Ambrosia beetles have not been considered effective vectors of plant pathogens because they generally lay their eggs in dead or dying trees. In the case of $X$. glabratus, successful egg-laying galleries have been commonly observed in the main stems of redbay trees in the advanced stages of laurel wilt or after trees have died. However, we have also observed isolated and infrequent beetle tunnels with $X$. glabratus on stems and branches of redbay trees in the early stages of wilt when sapwood discoloration is localized and wilting of foliage may be evident in only one or a few branches. In addition, we have observed aborted tunnels similar in diameter to those produced by $X$. glabratus in stems and branches as small as $1 \mathrm{~cm}$ in diameter. No eggs or larvae have been observed in these tunnels, but we have isolated the pathogen from discolored sapwood traced back to the tunnels. On the basis of our growth chamber studies, $X$. glabratus is capable of tunneling into healthy redbay seedlings as well as seedlings of other species in the Lauraceae and these test seedlings became infected. It appears that $X$. glabratus females tunnel into stems and branches, even those too small for brood development, and then abandon the tunnels without egg-laying. We hypothesize that the pathogen first infects healthy trees during such tunneling by $X$. glabratus and the trees later become suitable for brood production after the fungus has moved systemically throughout the main stem. It is likely that the larvae develop and feed on the pathogen in diseased trees, and mycangia of young female adults are colonized before emergence. Thus, the laurel wilt pathogen may be introduced into stems and branches of healthy trees by tunneling without egglaying, in a manner similar to the transmission of the Dutch elm disease fungi by their bark beetle vectors during maturation feeding in elm twigs $(23,47)$. However, to our knowledge, this behavior of tunneling without egg-laying has not been demonstrated for an ambrosia beetle. Little is known about $X$. glabratus in its native habitat, and there is no indication that this beetle and its fungal associate are capable of killing trees in Asian forests. Clearly, more work is needed on this critical stage in the disease cycle of laurel wilt.

There are currently about 3,400 species of ambrosia beetles worldwide that are taxonomically assigned to two subfamilies of the Curculionidae (13). Most species of wood-tunneling ambrosia beetles are regarded as opportunists that attack stressed or dying trees (15) and live only in recently cut, wounded, or weakened portions of woody plants (49). Kuhnholz et al. (28) indicate that in recent years there have been reports of secondary ambrosia beetles attacking apparently healthy trees and possibly causing tree death. In some instances, these beetles are exotics and appear to be more aggressive in their new habitats. Numerous, nonnative ambrosia beetles have been introduced into the United States over the last 100 years, but these beetles have not caused widespread mortality in native plant populations $(2,17,48)$. Some ambrosia beetles, such as Xylosandrus crassiusculus, have been responsible for mortality of apparently healthy plants in nurseries, urban landscapes, and orchards $(1,11,31,35)$. Others, such as $X$. compactus, have caused death of twigs on healthy trees in natural and urban landscapes (9).

The association of a wilt-causing fungus with an ambrosia beetle is unprecedented. The only previously documented case of extensive mortality of forest trees caused by an ambrosia beetle and a fungal symbi- ont appears to be the death of Quercus crispula Blume and Q. serrata Thumb (ex Murray) in Japan associated with Raffaelea quercivora, a fungal associate of the ambrosia beetle Platypus quercivorus $(26,27)$. This ambrosia beetle is thought to be indigenous to Asia and the decline of oaks in Japan has been documented since the 1930s (25). The attacked trees appear to be weakened by drought or other agents, and mass attacks by $P$. quercivorus are necessary for the oak trees to die $(12,26)$. $R$. quercivora is thought to facilitate tree death through localized colonization of the tree in the vicinity of the ambrosia beetle galleries, but the fungus does not colonize the host systemically $(12,32,33)$. In contrast, the Raffaelea sp. that causes laurel wilt is a very aggressive vascular wilt pathogen that is capable of colonizing the entire tree from a single introduction into small branches or stems, and the fungus appears to predispose the trees to egg-laying attacks by $X$. glabratus.

Laurel wilt has the potential to move very rapidly within stands of redbay as illustrated in the mortality data collected at the Timucuan Ecological and Historic Preserve. These data are consistent with observations and reports from other areas where the disease has occurred. For instance, reports of dying redbay on Hilton Head Island, SC and surrounding areas began in 2003, 1 year after the first detection of the beetle at nearby Port Wentworth, GA. According to local newspaper accounts, the first reports of redbay mortality on Hilton Head Island may have occurred as early as 2002 , but by the fall of 2004, officials on Hilton Head Island were estimating that they had lost approximately $80 \%$ of the redbay population. Likewise, park officials at Hunting Island State Park, SC reported that they had not observed redbay mortality in the fall of 2004, but in the spring of 2005, the first losses of redbay were observed, and as of October 2006, approximately $80 \%$ of the island's redbay have died of the disease (S. W. Fraedrich, unpublished data). At other sites in Georgia and South Carolina where the disease has been observed since 2004, almost all of the redbay trees have succumbed to the disease (S. W. Fraedrich, personal observation). Compared with larger diameter trees, seedlings appear much less affected by the disease, presumably because they are not as readily attacked by $X$. glabratus. In addition, sprouting of redbay at the groundline of dead trees has been observed at numerous locations. Some sprouts have died, but many others continue to grow.

On the basis of the results of these studies and the association of $X$. glabratus with species in the family Lauraceae in Asia and the United States, there is reason to be concerned that the wilt associated with redbay could affect additional members of this family in the Americas. Recent obser- 
vations of the wilt on sassafras, pondberry (a federally endangered species), and pondspice (a species endangered in Florida and threatened in Georgia), as well as results of pathogenicity tests presented in this study, provide support for this concern. Various species in the Lauraceae are common components of forests in other regions of the United States and other countries in the Western Hemisphere. For example, California laurel, Umbellularia californica (Hook and Arn) Nutt., is common in California and Oregon (46). Additionally, there is great diversification of the Lauraceae in Central and South America, and numerous species of this family are major components of tropical forests there (39). Last, avocado is a species indigenous to Central America and is commercially grown in Florida and California. Our evaluation of avocado indicates that it is also susceptible to laurel wilt, although the response was less consistent compared with other species in the Lauraceae that we tested. We are continuing to assess the risk and impact of $X$. glabratus and the Raffaelea $\mathrm{sp}$. to this valuable crop species as well as other species in the Lauraceae.

\section{ACKNOWLEDGMENTS}

We thank James Johnson and Chip Bates (Forest Health Specialists, Georgia Forestry Commission) and Laurie Reid and Andy Boone (Forest Health Specialists, South Carolina Forestry Commission) for their help in locating sites with wilted redbay, sassafras, pondspice, and pondberry and sharing their observations and thoughts. We also thank Don Duerr (Forest Health Protection, USDA Forest Service, Atlanta, GA) for securing funding to support portions of this work. Richard Bryant (National Park Service, Timucuan Ecological and Historic Preserve, Jacksonville, FL) is gratefully acknowledged for providing site access and field assistance. Laboratory assistance from Susan Best (USDA Forest Service, Athens, GA) and Joseph Steimel (Iowa State University, Ames) is greatly appreciated. Last, the senior author is grateful to Kathyrn Kromroy (Minnesota Department of Agriculture, St. Paul) who observed extensive redbay mortality during a trip to Hilton Head Island, SC in August of 2004 and thought there was more to the problem than just drought.

\section{LITERATURE CITED}

1. Atkinson, T. H., Foltz, J. L., and Wilkinson, R. C. 1988. Xylosandrus crassiusculus (Motschulsky), an Asian ambrosia beetle recently introduced into Florida (Coleoptera: Scolytidae). Fla. Dep. Agric. Consum. Serv. Div. Plant Ind. Entomol. Circ. 310. Gainesville, FL.

2. Atkinson, T. H., Rabaglia, R. J., and Bright, D. E. 1990. Newly detected exotic species of $X y$ leborus (Coleoptera: Scolytidae) with a revised key to species in eastern North America. Can. Entomol. 122:93-104.

3. Batra, L. R. 1967. Ambrosia fungi: A taxonomic revision and nutritional studies of some species. Mycologia 59:976-1017.

4. Beaver, R. A. 1989. Insect-fungus relationships in the bark and ambrosia beetles. Pages 121143 in: Insect-Fungus Interactions. N. Wilding, N. M. Collins, P. M. Hammond, and J. F. Webber, eds. Academic Press, London.

5. Brendemuehl, R. H. 1990. Persea borbonia (L.) Spreng. Redbay. Pages 503-506 in: Silvics of North America. Vol. 2, Hardwoods. R. M. Burns and L. H. Honkala, Technical Coordinators. Agric. Handb. 654. US Government Print- ing Office, Washington, DC.

6. Brown, C. L., and Kirkman, L. K. 1990. Trees of Georgia and Adjacent States. Timber Press, Portland, OR.

7. Cassar, S., and Blackwell, M. 1996. Convergent origins of ambrosia fungi. Mycologia 88:596-601.

8. Coker, W. C., and Totten, H. R. 1945. Trees of Southeastern States. The University of North Carolina Press, Chapel Hill.

9. Dixon, W. N., and Woodruff, R. E. 1982. The black twig borer, Xylosandrus compactus (Eichhoff) (Coleoptera: Scolytidae). Fla. Dep. Agric. Consum. Serv. Div. Plant Ind. Entomol. Circ. 250. Gainesville, FL.

10. Dunkin W. H., and Dunkin, M. B. 1988. Trees of the Southeastern United States. The University of Georgia Press. Athens, GA

11. Dute, R. R., Miller, M. E., Davis, M. A., Woods, F. M., and McLean, K. S. 2002. Effects of ambrosia beetle attack on Cercis canadensis. IAWA J. 23:143-160.

12. Esaki, K., Kato, K., and Kamata, N. 2004. Stand-level distribution and movement of Platypus quercivorus adults and patterns of incidence of new infestation. Agric. For. Entomol. 6:71-82.

13. Farrell, B. D., Sequeira, A. S., O'Meara, B. C., Normark, B. B., Chung, J. H., and Jordal, B. H. 2001. The evolution of agriculture in beetles (Curculionidae: Scolytinae and Platypodinae). Evolution 55:2011-2027.

14. Fernald, M. L. 1945. Botanical specialties of the Seward Forest and adjacent areas of southeastern Virginia. Rhodora 47:149-182.

15. Francke-Grosmann, H. 1967. Ectosymbiosis in wood-inhabiting insects. Pages 142-206 in: Symbiosis. Vol. 11, S. M. Henry, ed. Academic Press, New York.

16. Gilman, E. F., and Watson, D. G. 1994. Persea borbonia: Redbay. Fla. Coop. Ext. Serv. Inst. Food Agric. Sci. Fact Sheet St-436. University of Florida. Gainesville.

17. Haack, R. A. 2006. Exotic bark- and woodboring Coleoptera in the United States: Recent establishments and interceptions. Can. J. For. Res. 36:269-288.

18. Harrington, T. C. 1981. Cycloheximide sensitivity as a taxonomic character in Ceratocystis. Mycologia 73:1123-1129.

19. Harrington, T. C. 1992. Leptographium. Pages 129-133 in: Methods for Research on Soilborne Phytopathogenic Fungi. L. L. Singleton, J. D. Mihail, and C. M. Rush, eds. American Phytopathological Society, St. Paul, MN.

20. Harrington, T. C. 1993. Diseases of conifers caused by Ophiostoma and Leptographium. Pages 161-172 in: Ceratocystis and Ophiostoma, Taxonomy, Ecology and Pathogenicity. M. J. Wingfield, K. A. Seifert, and J. F. Webber, eds. American Phytopathological Society, St. Paul, MN.

21. Harrington, T. C. 1993. Biology and taxonomy of fungi associated with bark beetles. Pages 37-58 in: Beetle-Pathogen Interactions in Conifer Forests. T. D. Schowalter and G. M. Filip, eds. Academic Press, New York.

22. Harrington, T. C. 2005. Ecology and evolution of mycophagous bark beetles and their fungal partners. Pages 257-292 in: Insect-Fungal Associations: Ecology and Evolution. F. E. Vega and M. Blackwell, eds. Oxford University Press, Inc. New York.

23. Jacobi, W. R, Koski, R. D., Harrington, T. C., and Witcosky, J. J. 2007. Association of Ophiostoma novo-ulmi with Scolytus schevyrewi (Scolytidae) in Colorado. Plant Dis. 91:245247.

24. Jones, K. G., and Blackwell, M. 1998. Phylogenetic analysis of ambrosial species in the genus Raffaelea based on 18S rDNA sequences. Mycol. Res. 102:661-665.

25. Kamata, N., Esaki, K., Kato, K., Igeta, Y., and Wada, K. 2002. Potential impact of global warming on deciduous oak dieback caused by ambrosia fungus Raffaelea sp. carried by ambrosia beetle Platypus quercivorus (Coleoptera: Platypodidae) in Japan. Bull. Entomol. Res. 92:119-126.

26. Kinuura, H., and Kobayashi, M. 2006. Death of Quercus crispula by inoculation with adult Platypus quercivorus (Coleoptera: Platypodidae). Appl. Entomol. Zool. 41:123-128.

27. Kubono, T., and Ito, S. 2002. Raffaelea quercivora sp. nov. associated with mass mortality of Japanese oak, and the ambrosia beetle (Platypus quercivorus). Mycoscience 43:255260.

28. Kuhnholz, S., Borden, J. H., and Uzunovic, A. 2001. Secondary ambrosia beetles in apparently healthy trees: Adaptions, potential causes and suggested research. Integr. Pest Management Rev. 6:209-219.

29. Little, E. L., Jr. 1979. Checklist of United States Trees (Native and Naturalized). U.S Department of Agriculture, Forest Service, Agric. Handb. 541. U.S. Government Printing Office, Washington, DC.

30. Luna, L. G. 1968. Manual of Histologic Staining Methods of the Armed Forces Institute of Pathology. 3rd ed. McGraw-Hill Book Company, New York.

31. Mizell, R., Braman, S. K., Sparks, B., and Hudson, W. 1994. Outbreak of the Asian ambrosia beetle, Xylosandrus crassiusculus (Motschulsky), is cause for concern. Proc. South. Nursery Assoc. Res. Conf. 39:191-193.

32. Murata, M., Yamada, T., and Ito, S. 2005. Changes in water status in seedlings of six species in the Fagaceae after inoculation with Raffaelea quercivora Kubono et Shin-Ito. J. For. Res. 10:251-255.

33. Murata, M., Yamada, T., Matsuda, Y., and Ito, S. 2007. Discolored and non-conducive sapwood among six Fagaceae species inoculated with Raffaelea quercivora. For. Pathol. 37:7379 .

34. Norris, D. M. 1979. The mutualistic fungi of Xyleborini beetles. Pages 53-63 in: Insect-Fungus Symbiosis: Nutrition, Mutualism, and Commensalism, L. R. Batra, ed. Allanheld, Osmun and Co., Montclair, NJ.

35. Oliver, J. B., and Mannion, C. M. 2001. Ambrosia beetle (Coleoptera: Scolytidae) species attacking chestnut and captured in ethanolbaited traps in middle Tennessee. Environ. Entomol. 30:909-918.

36. Paulin, A. E., and Harrington, T. C. 2000 Phylogenetic placement of anamorphic species of Chalara among Ceratocystis species and other ascomycetes. Stud. Mycol. 45:209-222.

37. Rabaglia, R. J., Dole, S. A., and Cognato, A. I 2006. Review of American Xyleborina (Coleoptera: Curculionidae: Scolytinae) occurring north of Mexico, with an illustrated key. Ann. Entomol. Soc. Am. 99:1034-1056.

38. Radford, A. E., Ahles, H. E., and Bell, C. R. 1968. Manual of the Vascular Flora of the Carolinas. The University of North Carolina Press. Chapel Hill.

39. Rohwer, J. G. 1993. Lauraceae. Pages 366-391 in: The Families and Genera of Vascular Plants II. K. Kubitzki, J. G. Rohwer, and V. Bittrich, eds. Springer-Verlag, Berlin.

40. Rollins, F., Jones, K. G., Krokene, P., Solheim, H., and Blackwell, M. 2001. Phylogeny of asexual fungi associated with bark and ambrosia beetles. Mycologia 93:991-996.

41. Sargent, C. S. 1922. Manual of the Trees of North America. Dover Publications, Inc. New York.

42. Schedl, W. 1962. Ein Beitrag zur Kenntnis der Pilzubertragungsweise bei xylomycetophagen Scolytiden (Coleoptera). Sitzungsber. Oesterr. Akad. Wiss. ABT. I. 171:363-387.

43. Scott, J. A. 1986. The Butterflies of North America: A Natural History and Field Guide. Stanford University Press. Stanford, CA. 
44. Sinclair, W. A., and Lyon, H. H. 2005. Diseases of Trees and Shrubs. 2nd ed. Cornell University Press, Ithaca, N.Y.

45. Six, D. L. 2003. Bark beetle-fungus symbioses. Pages 99-116 in: Insect Symbiosis. K. Bourtzis and T. Miller, eds. CRC Press, Boca Raton, FL.

46. Stein, W. I. 1990. Umbellularia californica (Hook. And Orn) Nutt. Pages 826-834 in: Silvics of North America. Vol. 2. Hardwoods. R.
M. Burns and L. H. Honkala, Technical Coordinators. Agric. Handb. 654. US Government Printing Office. Washington, DC.

47. Webber, J. F., and Gibbs, J. N. 1989. Insect dissemination of fungal pathogens of trees. Pages 161-193 in: Insect-Fungus Interactions. N. Wilding, N. M. Collins, P. M. Hammond, and J. F. Webber, eds. Academic Press, London.

48. Wood, S. L. 1977. Introduced and exported
American Scolytidae (Coleoptera). Great Basin Nat. 37:67-74.

49. Wood, S. L. 1982. The bark and ambrosia beetles of North and Central America (Coleoptera: Scolytidae), a taxonomic monograph Great Basin Nat. Mem. 6:1-1359.

50. Wood, S. L., and Bright, D. E. 1992. A catalog of Scolytidae and Platypodidae (Coleoptera), Part 2: Taxonomic index. Vol. A and B. Great Basin Nat. Mem. No. 13. 